\title{
AS CONCEPÇÕES DE LEI NATURAL E DE LEI SECULAR CONTIDAS NA REFLEXÃO FILOSÓFICO-TEOLÓGICA DE ORÍGENES
}

\author{
The Natural Law and Secular Law Conceptions contained in the Origen's \\ Philosophical-Theological Reflexion
}

Sidnei Francisco do Nascimento ${ }^{1}$

\begin{abstract}
RESUMO: O método de interpretação alegórica de Orígenes se apropriará de uma passagem do Evangelho segundo São Mateus $(22,21)$ que trata a respeito da célebre passagem de "dar a César o que é de César e a Deus o que é de Deus" e de um trecho da Epistola aos Romanos (13,1-14) que discorre a respeito da submissão da alma à autoridade civil. Tal exegese apresentará a complementaridade, embora com significados diferentes, entre as concepções de lei natural e de lei secular. A correspondência entre uma lei e outra, transitará entre o mundo sensível e o inteligível ou, dito de outra forma, entre o mundo terreno e o mundo espiritual, que terá o livrearbítrio como um elemento indispensável, porque se traduzirá num dever de consciência, que incidirá na noção tricotômica de alma paulina movimentando-se entre os desejos da carne e os desejos do espírito.
\end{abstract}

PALAVRAS-CHAVE: Lei Secular; Lei Natural; Alma; Livre-Arbítrio; Orígenes.

ABSTRACT: The Origen's allegorical interpretation method will hold of a passage of the Gospel according to St Matthew $(22,21)$ that deals the notorious passage "Render therefore unto Caesar the things which are Caesar's; and unto God the things that are God's." and a passage from The Romans $(13,1-14)$ that describes the soul's submission to the civil authority. That exegesis will represent the complementarity, although with different meanings, between the natural law and secular law conceptions. The correspondence between one lay and the other will transit between the sensitive worlds and the intelligible world or, in other words, between the earthly world and the spiritual world, that will have the free will as an indispensable element, because it will be translated into an awareness duty, which will focus on the trichotomic notion of Pauline soul moving among the wishes of the flash and the wishes of the spirit.

KEYWORDS: Secular Law; Natural Law; Soul; Free Will; Origen.

O método exegético articulado por Orígenes para ler e interpretar as Sagradas Escrituras se desenvolve em dois níveis interpretativos: o literal e o espiritual, que, por

\footnotetext{
${ }^{1}$ Doutor em filosofia pela Pontifícia Universidade Católica de São Paulo (PUC-SP) e professor de filosofia no Programa de Pós-Graduação em Filosofia da Universidade Federal do Maranhão (UFMA). E-mail: sidnei.fn@ufma.br
} 
sua vez, se correspondem às duas dimensões do real, a saber, o mundo sensível e o mundo inteligível. A interpretação alegórica pode ser compreendida como um procedimento técnico pelo qual o autor procurava uma certa expressão ou significado diferente do literal, que, nesse sentido, poderia também ser aplicado indiferentemente aos conteúdos pagãos e cristãos. Para se compreender a crítica e a análise que Orígenes desenvolverá a respeito da Igreja e do Império romano mediante os conceitos de lei natural e de lei secular, devemos, antes, considerar que, por intermédio de uma elaborada técnica de interpretação alegórica, o autor estabelecerá uma correspondência, por um lado, entre a lei natural e o mundo inteligível, e, em contrapartida, do ponto de vista literal, à luz do conceito de lei secular, ele nos remeterá à dimensão do sensível, que incluirá, do mesmo modo, a perspectiva histórica.

Os conceitos de lei natural e de lei secular não são excludentes, mas diferentes, e em grande medida se completam. Os limites entre uma lei e outra são muito tênues. Em seu texto, Teologia Politica: La rappresentazione del potere e il potere della rappresentazione, ${ }^{2}$ Marco Rizzi nos sugere que a teologia política, compreendida como teologia do visível, estará para o mundo sensível da mesma forma como a imagem da autoridade imperial estará para os deuses, e, por conseguinte, de maneira semelhante, a imagem da Igreja representará a autoridade religiosa. ${ }^{3}$ O inteligível e o espiritual, bem como o sensível e o histórico, se entrelaçam quando admitimos que tanto a imagem do imperador quanto os representantes da Igreja possuem forças o suficiente para estabelecerem um elo entre a eternidade e o tempo, entre a ontologia e a história. Estamos falando de um poder visível na terra que possui a eficácia suficiente para representar o poder invisível de Deus.

Orígenes, um autor do século III de nossa era, fora membro como professor da Catequese de Alexandria. Vivenciou adversidades de toda sorte, não só porque viveu num tempo em que Alexandria era considerada como uma das cidades mais turbulentas do mundo, dentro da qual o cristianismo sobreviveu, mas também por ter sido considerado

\footnotetext{
${ }^{2}$ RIZZI, M. La rappresentazione del potere e il potere della rappresentazione in: BETTIOLO P. e FILORAMO G. (orgs.). Il Dio Mortale: Teologie politiche tra antico e contemporaneo. Brescia: Morcelliana, 2002, p. 285.

${ }^{3}$ Ambrósio responde ao imperador, por ocasião do conflito às portas da Basílica, na cidade de Milão, em 386 d. C., retomando a célebre passagem em Mateus, 22:21, para dizer que a igreja é a imagem de Deus invisível: "façamos do homem a sua imagem, depois sua semelhança". Verificamos que tanto em Orígenes quanto em Ambrósio a Igreja pertence a Deus e não deve ficar sob os domínios do imperador, donde a máxima: "Imperator intra ecclesiam, non supra ecclesiam est". Ambrósio In: Sermo contra Auxentium, 32.2 apud Rizzi, M. Romans 13 Early Christian Exegesis. In: J. BAUN, A. CAMIERON, M. EDWARDS, M. VINZENT (orgs.). Studia Patristica Vols. XLIV-XLIX. Paris: Peeters, 2010, p. 231.
} 
imprudente demais pela maneira como se apropriou da filosofia platônica, no que diz respeito à oposição platônica entre o inteligível e o sensível; não obstante, se colocava contrário às leis sobre o culto em louvor aos deuses particulares de cada país e, em especial, ao culto que se dedicava aos deuses romanos para exaltar o poder do imperador. Orígenes assistiu os martírios, vivenciou o perigo da morte, praticou as mais duras asceses e reconheceu a hostilidade dos heréticos. ${ }^{4}$ Herdou do médio platonismo alguns traços muito característicos de seu jeito de pensar a religião e o poder temporal, tais como a ideia de recuperação do suprassensível, do imaterial, do transcendente e da teoria das ideias platônicas paralela à estrutura do mundo incorpóreo, ${ }^{5}$ embora devêssemos reconhecer que Orígenes não fizesse uso da tripartição da alma platônica entre a alma racional, irascível e concupiscível, mas sua tripartição é de origem paulina, que concebe a noção de alma dividida entre o espírito, a alma superior e inferior e o corpo. ${ }^{6}$ De um modo geral sua formação intelectual fez com que secundasse o mundo material e toda realidade corpórea em detrimento do mundo espiritual. Dessa forma, concebia o mundo aparente e ilusório da matéria apenas como referência ao espírito racional, inteligente, santo e bem-aventurado. ${ }^{7}$

Attila Jakab, em seu livro Ecclesia alexandrina: évolution sociale et institutionnelle du christianisme alexandrin (IIe et IIIe siècles), escreve que o movimento cristão possuía uma sensibilidade espiritual e religiosa sem burocracia funcional, e sem ritualismos de deveres religiosos. ${ }^{8}$ É o invisível, espiritual, inteligível em detrimento do visível, material e corpóreo. Orígenes privilegiará a lei da natureza como uma lei de Deus inscrita nos corações dos homens por meio da revelação. Será o logos divino presente em todas as coisas, até mesmo nas mais ínfimas, que se corresponderão ao universalismo cristão. Não só a alma se constitui como "a imagem do Criador". (Cl 3,10), como a Igreja deve se manter como a imagem do Deus invisível: Façamos o homem a sua imagem $e$ semelhança. (Gn. I, 26). Assim sendo, se tudo converge para o mundo inteligível, como ficará a imagem do imperador segundo as tradições romanas? E o culto à fortuna do imperador? E a lei secular, correlata à constituição humana? E o juramento aos deuses

\footnotetext{
${ }^{4}$ CADIOU, R. Junesse d'Origène: histoire de l'École d'Alexandrie au début du IIIe siècle. Paris: G. Beauchesne et ses Fils, 1935, p. 92.

${ }^{5}$ ORÍGENES. Contra Celso. Tradução de Orlando Reis. São Paulo: Paulus, 2004, p. 12.

${ }^{6}$ CROUZEL, H. SI. Origène et la philosophie. Paris: Aubier, 1962, p. 59.

${ }^{7}$ ORÍGENES. Contra Celso. Tradução de Orlando Reis. São Paulo: Paulus, 2004, p. 656.

${ }^{8}$ JAKAB ATTILA. Ecclesia alexandrina: évolution sociale et institutionnelle du christianisme alexandrin (IIe et IIIe siècles). Bern. P. Lang, 2001, p. 63.
} 
pagãos? Como escreve Marco Rizzi, ${ }^{9}$ estaria contida no cristianismo primitivo a semente do laicismo moderno quando da separação entre a religião e autoridade política, entre a Igreja e o Estado?

Abordaremos a seguir a dimensão histórica da constituição humana e a sua correspondente dimensão ontológica quando aproximamos a legislação do Estado ao seu aspecto sensível, visível e pragmático, não menos importante para o ordenamento jurídico necessário à vida associada, a qual Orígenes reconhecerá e respeitará, mas relativizará em detrimento de uma visão religiosa que não despreza a lei civil, mas que a considera como a representação do logos divino, como modelo e referência para a conduta moral.

\section{Tributai honra ao Rei (1Pd 2,17)}

Uma série de acusações afloravam pelo Império contra os cristãos, tais como suspeita de sedição política, perturbação da ordem e transgressão da ordem estabelecida. Os contrastes não faltavam de uma política imperial praticada em relação ao cristianismo, desde uma calmaria passageira até as perseguições mais intensas. Sabemos que na época de Antonino Pio (138 d.C.-161 d.C.) e de Marco Aurélio (161 d.C.-180 d.C.) abundaram os panfletos de todas as tendências, por outro lado, por ocasião da perseguição de Sétimo Severo (193 d. C.-211 d.C.), ou do massacre impetrado por Antônio Caracalla (215 d. C.216 d.C.), além de Orígenes ter perdido o pai, foram confiscados todos os bens da família, como era costume dos agentes do tesouro imperial.

Proponho a leitura de dois textos muito expressivos e oportunos para contextualizar a reflexão a respeito da relação entre a autoridade religiosa e a autoridade civil, conferindo maior ênfase neste capítulo à função legislativa do Estado em oposição à Igreja compreendida numa perspectiva origenista. A obra Contra Celso está provida de várias passagens onde Orígenes estabelece, de maneira bastante categórica, críticas aos desvios de conduta e à devassidão dos imperadores, quando, por exemplo, os associa aos "demônios terrestres, considerados como deuses pelos que ignoram sua natureza". ${ }^{10}$ Do mesmo modo, veremos outra obra do mesmo autor, Commento alla lettera ai Romani, livro IX, do capítulo XXV ao XXXIII, que apresenta, por sua vez, um refinado trabalho

\footnotetext{
${ }^{9}$ RIZZI, M. Romans 13 Early Christian Exegesis. In: J. BAUN, A. CAMIERON, M. EDWARDS. M. VINZENT (orgs.). Studia Patristica Vols. XLIV-XLIX. Paris: Peeters, 2010, p. 228.

${ }^{10}$ ORÍGENES. Contra Celso. Tradução de Orlando Reis. São Paulo: Paulus, 2004, p. 229.
} 
de exegese, elaborado através da Epístola aos Romanos (13,1-14) com o claro propósito de distinguir o que diz respeito ao poder temporal frente ao poder espiritual. ${ }^{11}$

Observa-se uma tensão entre poder político e autoridade religiosa quando examinamos suas considerações referentes à lei da natureza e à lei escrita:

Devemos, portanto, falar de duas leis em geral: uma, a lei da natureza, da qual podemos dizer que Deus é o autor; a outra, a lei escrita das cidades. Quando a lei escrita não contradiz a Deus, convém não perturbar os cidadãos com leis estrangeiras. Mas, quando a lei da natureza, quer dizer de Deus, ordena o contrário da lei escrita, vê se a razão não ordena que dispensemos os textos e a intenção dos legisladores e nos entreguemos ao Deus legislador e escolhamos uma vida conforme com o seu logos, ainda que tenhamos de enfrentar riscos, mil sofrimentos, a morte e a infâmia. ${ }^{12}$

A lei da natureza vinda de Deus é anterior à lei escrita que envolve a constituição do Estado e que lhe confere universalidade quando introjetada nos corações dos homens, ou, dito de outra forma, quando se transforma numa lei de consciência. O logos divino envolve as leis do Estado e se converte na lei moral mediada pelo filho de Deus que habita entre os homens. Não se trata de subjugar as leis escritas simplesmente, mas reconhecer que, se homem foi criado à imagem de Deus ${ }^{13}$ e a imagem de Deus é seu logos, então temos de reconhecer que a natureza humana possui um princípio hegemônico, racional aplicado pelo raciocínio ${ }^{14}$ por meio do qual as leis escritas foram constituídas. Segundo Marco Rizzi, em seu texto Salvezza e legge: Romani 2:14 da Origene ad Agostino, há uma lei civil autônoma plasmada sobre a lei natural, comum a todos os seres humanos enquanto criados por Deus. ${ }^{15}$

O que está em discussão nas refutações que Orígenes faz a Celso é a maneira como louvar os deuses, contrária ao que o alexandrino considerava como culto verdadeiro. De um lado a tradição e a exaltação dos valores romanos, que remontavam uma estratégia comum da retórica e da epidítica-política romana, que Celso pretendia conservar; por outro lado, a defesa de uma lei natural e espiritual que se traduzia numa noção de "Deus racional e supremo" "16, que incidirá numa consciência tranquila sem oblações e

\footnotetext{
${ }^{11}$ ORIGENE. Commento alla lettera ai romani. Tradução de Francesca Cocchini. Genova: Marietti, 1986.

12 ORÍGENES. Contra Celso. Tradução de Orlando Reis. São Paulo: Paulus, 2004, p. 421.

${ }^{13} \mathrm{O}$ filho como a imagem de Deus, ver também: Jo 14,9; $\mathrm{Hb} 1,3 ; \mathrm{Cl} 1,15 ; 2 \mathrm{Cor} 4,4$.

${ }^{14}$ ORÍGENES. Contra Celso. Tradução de Orlando Reis. São Paulo: Paulus, 2004, p. 364.

${ }^{15}$ RIZZI, M. Salvezza e legge: Romani 2, 14 da Origene ad Agostino. In: LAURA GAFFURI e ROSA M. PARRINELLO (orgs.). Verbum e ius - Predicazione e sistemi giuridici nell'Occidente medievale. Firenze: Firenze University Press, 2018, p. 25.

${ }^{16}$ ORÍGENES. Contra Celso. Tradução de Orlando Reis. São Paulo: Paulus, 2004, p.679.
} 
demonstrações de uma piedade religiosa com práticas exteriores de devoção. Não há fronteira entre a contemplação e a ação, a prática não é senão esta ascese ${ }^{17}$ íntima. ${ }^{18}$

As estátuas, as oferendas agradáveis a Deus não são obras de artesãos vulgares, mas do Logos de Deus que as delineia e forma em nós. São as virtudes, imitações do "Primogênito de toda criatura" no qual estão os modelos da justiça, da temperança, da força, da sabedoria, da piedade e das demais virtudes. Portanto, todos os que, segundo o divino Logos, edificaram em si mesmos a temperança, a justiça, a força, a sabedoria, a piedade e as obras-primas das demais virtudes trazem em si mesmos estátuas. ${ }^{19}$

Orígenes nos diz que devemos nos submeter às autoridades constituídas porque, em primeiro lugar, não há autoridade que não venha de Deus. A seguir, ele recomenda que façamos pedidos, orações, súplicas e ações de graças por todos os homens, pelos reis e todos o que detêm a autoridade $(1 \mathrm{Tm} 2,1-2)^{20}$. Sublinhamos que o critério do logos e o critério ético são estritamente ligados. A alma racional que conhece e julga, que contempla o logos divino como atributo da divindade fará o bem, agirá com justiça e força e executará o que é o bem. Se a lei secular é derivada da lei de Deus, obedecê-la é ao mesmo tempo obedecer aos governantes probos e honestos.

Mas seguimos com as sugestões de Orígenes quando nos recomenda a ler dentro da obra Contra Celso seu comentário sobre a Epístola aos Romanos com explicações longas e variadas sobre as correspondências entre o poder da lei e o do logos de Deus. Segundo o alexandrino, Paulo estabelece preceitos e ordena que a alma em nós deve estar submetida à autoridade do mundo. Para ratificar seu ponto de vista ele recorre à célebre passagem contida em Mateus (22,21), em que está contida a inscrição do imperador, digo, de restituir a César o que é de César. Orígenes constata que, se não há nada para restituir a César, não se deve se submeter à autoridade superior, mas quem, ao contrário, possui dinheiro ou posses ou qualquer negócio mundano escute: toda alma seja submetida às autoridades superiores (Rm 13,1).

Há um pormenor importantíssimo em sua alegoria que deve ser sublinhado, pois Paulo não está dizendo que seja o espírito submetido às autoridades superiores, mas a alma. Assim sendo, o homem é apresentado algumas vezes com o termo "alma", às vezes como "carne" e às vezes com o termo "espírito". Essa tricotomia antropológica de Paulo sobre

\footnotetext{
${ }^{17} \mathrm{O}$ significado de Ascese para Orígenes: ciência religiosa; interpretação das passagens misteriosas da bíblia; a teologia como resultado; todas as coisas que se adquirem com muita pena e que não são méritos senão pela virtude.

${ }^{18}$ CAIDIOU, R. La jeunesse d'Origène: histoire de l'ecole d'Alexandrie au début du IIIe siècle. Paris: G. Beauchesne et ses Fils, 1935, p. 97.

${ }^{19}$ ORÍGENES. Contra Celso. Tradução de Orlando Reis. São Paulo: Paulus, 2004, p. 623.

${ }^{20}$ Idem. p. 681.
} 
a noção de alma (pneuma, psyche, sarx), que Orígenes retoma, se divide entre a teologia do espírito e sua correlata dimensão mística, a teologia da história e sua dimensão sensível, ou sárquica, sem nos esquecer da teologia moral, quando Orígenes admite que há um "dever de consciência" no momento da decisão se devemos ou não obedecer às leis da letra ou às leis do Espírito.

Todavia, ocorre saber que a lei não foi colocada para o justo, mas para o injusto e os rebeldes, os malvados, os homicidas, os impuros, os perjúrios e todos os outros deste tipo. (1Tm 1: 9) São esses de fato que temem a lei. Quem, ao contrário, faz o bem, ou seja, quem cumpre o que é bom não por temor à lei, mas por amor do bem, este homem agora não vive sob a lei da letra, mas sob a lei do Espírito. ${ }^{21}$

Preceitos tais como obedecer à lei, fazer o que é o bem ou, do mesmo modo, que não precisamos dever nada a ninguém, a não ser o amor mútuo, $(\mathrm{Rm} 13,8-9)$ pertencem à esfera da psyche porque é exatamente neste domínio que reside o livre-arbítrio da vontade, quero dizer, as ações ou deliberações que envolvem o querer e naturalmente a responsabilidade sobre as consequências de nossas escolhas e decisões. Mas sobre essa hipóstase paulina (psyche) retomada pela exegese de Orígenes que envolve, por sua vez, algum motivo de consciência (lex naturalis) do agente da ação como um elemento propulsor que possibilitará e conduzirá a transcendência da alma para Deus, isso veremos no próximo capítulo, neste momento, retornamos à dimensão sárquica do poder.

$\mathrm{Na}$ Epístola aos Romanos $(13,13)$ Paulo escreve que devemos abandonar as "obras das trevas" que Orígenes considerará como as "obras da carne", tais como a devassidão, a libertinagem, as rixas, os ciúmes que não convêm aos homens dotados de razão, mas às "bestas feras". Como vícios da carne ou, dito de outro modo, como vícios da alma, caberá às leis escritas punirem as condutas desviantes e estabelecer a punição correspondente ao grau de injustiça cometida, assim, compreendemos melhor aquela passagem que nos sugere que a lei não foi feita para os justos, mas para os injustos e todo gênero de concupiscência.

Os que vivem segundo a carne devem se submeter às leis do Estado e devem obediência ao imperador. Devem-se respeitar as prerrogativas que o imperador possui de administrar e gerir a coisa pública, desde a cobrança de impostos, taxas e tudo o que envolve os assuntos do Estado. Deve tributos aos poderes seculares quem vive segundo a carne e pensa nas coisas que pertencem à carne $(\mathrm{Rm} 8,5)$.

\footnotetext{
${ }^{21}$ ORIGENE. Commento alla lettera ai romani. Tradução de Francesca Cocchini. Genova: Marietti, 1986,
} p. 127. 
Mas quando admitimos que o governante, envolvido pela dimensão sárquica, tenha sido seduzido pelas coisas desse mundo, a orientação sugerida pelo alexandrino é que devemos protestar, ainda que tenhamos de enfrentar riscos e muitos sofrimentos; talvez resida nesse ponto a suspeita de sedição e a acusação movida contra os cristãos que os transformavam como perturbadores da ordem. Orígenes conclui que o motivo da morte pelo fato de não se pagar os impostos seria indigno, mas a morte, para defender o que seja justo, seria digna. A situação se inverte quando a autoridade secular respeita os cânones da lei natural, e neste caso, aqueles que não pagarem os tributos deveriam fazê-lo e, se não o fizessem, deveriam ser perseguidos e acusados justamente pelos governantes, donde a máxima seria bem diferente daquela: o motivo da morte seria digno, mas a morte indigna. A passagem que nos sugere de dar a Cesar o que é de Cesar consiste na obediência ao poder secular como um lugar de jurisdição específica ${ }^{22}$ para o poder político, desde que o imperador respeite, por sua vez, a lei natural correspondente à lei de Deus.

\section{Lei natural}

Várias são as referências ao livre-arbítrio, tais como, "está em nosso poder nos servir da vista para o bem ou para o mal" (Rm 13,1), ou "Por isso é necessário estar submetido não apenas à causa da ira, mas também ao motivo da consciência" (Rm 13,5-6). No entanto, é necessário atinarmos a que a exegese de Agostinho, diferentemente da exegese de Orígenes, irá se apropriar da tripartição da concepção paulina de alma com algumas sutis e não menos importantes diferenças. ${ }^{23}$

Apenas como um contraponto para compreendermos melhor a exegese de Orígenes, salientamos que a discussão em torno da divisão a respeito da noção de alma, isto é, se ela possui duas ou três dimensões, chegou até Agostinho com algumas variações. O que nos interessa é enfatizar que há diferenças entre a tricotomia da noção de alma admitida por Orígenes e a concepção dualista contida na compreensão de espírito em Agostinho, o que do ponto de vista prático não mudará muito, porque tanto Orígenes quanto Agostinho

\footnotetext{
${ }^{22}$ RIZZI, M. Romans 13 Early Christian Exegesis. In: J. BAUN, A. CAMIERON, M. EDWARDS. M. VINZENT (orgs.). Studia Patristica Vols. XLIV-XLIX. Paris: Peeters, 2010, p. 230

${ }^{23}$ Sabemos que há uma oscilação da noção de alma em Orígenes: ora ele descreve um esquema ternário e sugere uma alma intermediária entre a carne e o espírito, e o livre-arbítrio estaria neste nível intermediário (psyque) e escolheria entre uma alma e outra, ora ele aponta para um esquema binário, quero dizer, que há uma alma como princípio vital que anima o corpo, constitutivamente oposto à alma superior. Assim, parecenos que Agostinho estaria muito mais vinculado à compreensão do esquema binário de alma do que ternário.
} 
concordavam que os cristãos deviam respeitar as leis seculares. No entanto, a estrutura antropológica se altera em relação à divisão tripartite da alma. "Agostinho marca um fim da tradição exegética de Orígenes" ${ }^{24}$, na medida em que comprimirá o livre-arbítrio em sua dimensão temporal, o que estará submetido objetivamente ao mundo celestial. Não há uma mesma alma dividida entre o que está dentro do corpo e o que está fora dele como intermediário entre o homem e Deus. Se Agostinho não concebe essa divisão, logo o livrearbítrio pertencerá apenas à dimensão secular em que a alma e o corpo formam uma unidade. ${ }^{25}$

Eis o que eu quero te explicar agora: o que põe o homem acima dos animais, seja qual for o nome com que designemos tal faculdade, seja mente ou espírito, ou com mais propriedade um e outro indistintamente, porque encontramos esses dois vocábulos também nos Livros Sagrados - quando, pois, esse elemento superior domina no homem e comanda a todos os outros elementos que o constituem, ele se encontra perfeitamente ordenado. ${ }^{26}$

Deduzimos que, no caso de Orígenes, as doutrinas materialistas ainda reverberavam em seus escritos, e a psicologia estoica que concebe a alma como centro de coordenação dos dados sensíveis reaparece, embora de maneira diferente, quando o próprio, em alguns dos seus escritos, nos diz que há uma sabedoria da carne e uma outra sabedoria do espírito. Agostinho, ao contrário, ao rejeitar completamente a teologia materialista dos estoicos, recusará ao mesmo tempo a ideia de que Deus como um sopro divino, atravessaria o cosmo da maneira como os estoicos concebiam.

Assim, pois, qualquer alma vale mais do que todo o ser corporal, e nenhuma alma pecadora, seja qual for a profundidade de sua queda, por mudança alguma, torna-se jamais um corpo. Nem se pode retirarlhe nada da perfeição que faz dela uma alma. Portanto, ela conservará sempre sua superioridade sobre o corpo. ${ }^{27}$

Mas voltemos à teologia tricotômica sobre a noção de alma em Orígenes e infiramos que a alma, dividida entre o espírito, a mente e o corpo (pneuma, psyque, sarxs) reaparece inserida nos âmbitos político, ontológico, epistemológico, moral e consequentemente religioso. Traduziremos esse esquema tripartite da noção de alma como se estivéssemos desenvolvendo uma "teologia da imagem" de ascendência alexandrina. Sua teologia

\footnotetext{
${ }^{24}$ RIZZI, M. Romans 13 Early Christian Exegesis. In: J. BAUN, A. CAMIERON, M. EDWARDS. M. VINZENT (orgs.). Studia Patristica Vols. XLIV-XLIX. Paris: Peeters, 2010, p.233.

${ }^{25}$ Ver também: AGOSTINHO. A Trindade. Livro X, 11.18. Tradução de Agustino Belmonte, O.A.R. São Paulo: Paulus, 1994, p. 331.

${ }^{26}$ AGOSTINHO. O livre-arbítrio. Tradução, organização, introdução e notas de Nair de Assis Oliveira. São Paulo: Paulus, 1995, p. 46.

${ }^{27}$ Idem, p. 167.
} 
explicita a definição de alma, e consequentemente à imagem do Filho de Deus, interpretada como a imagem de Deus invisível, distinguindo o homem como a imagem da imagem de Deus que se reflete na imagem de seu Filho.

Há, portanto, uma pessoa que é o Filho de Deus, imagem de Deus invisível (Rm 8,29), e uma imagem deste Filho, chamada imagem do Filho de Deus. Esta imagem, eu estimo que é a alma humana que assume o Filho de Deus, que vem a ser por sua virtude imagem da imagem de Deus. É esta alma humana que nós temos por imagem da imagem de Deus que Deus predestinou a vir a ser conforme aqueles que ele predestinou pela graça da sua presciência. ${ }^{28}$

A alma atravessará muitos degraus, sempre visando o bem comum do Universo, não do universo material, mas do universo do espírito, pois será primeiro em virtude do ser racional que Deus tudo criou. ${ }^{29}$ As filosofias da transcendência predominantes na Antiguidade tardia foram retomadas por Orígenes. Sublinhamos, mais uma vez, que, no meio cultural e filosófico a que o alexandrino pertenceu, tais filosofias, como o estoicismo, neopitagorismo, neoplatonismo e ainda mais o médio platonismo, foram determinantes para sua formação intelectual. ${ }^{30} \mathrm{O}$ nous platônico, o conhecimento racional e sua intuição mística prevaleceram, e o método exegético de Orígenes realizou essa síntese, como, por exemplo, no diálogo Teeteto, quando Platão sugere que o caminho de conversão da alma para Deus a constituirá como pura e santa com a ajuda da inteligência. Movimento muito parecido com o que ocorre no período helenístico e sobretudo nos escritos de Orígenes:

Assim é necessário tentar fugir o mais rapidamente possível deste mundo para dentro de outro. Ora, fugir assim é se render, o quanto possível, à semelhança de Deus, e ser semelhante a Deus, é ser justo e santo, com a ajuda da inteligência. ${ }^{31}$

Recorremos a Numenios e verificamos a semelhança apesar das diferenças entre o médio platonismo e o cristianismo com relação à tripartição da alma. Importante observar que o movimento de conversão da alma para Deus e da divisão da alma entre o incorporal e o material é muito parecido com a divisão da alma em duas ou três dimensões como está presente nos escritos de Orígenes. Concebem-se dois deuses se imaginarmos que há uma alma superior e uma inferior; no entanto, Numenios admitia que a mesma alma

${ }^{28}$ ORIGÈNE. Philocalie 21-27. Sur le Libre Arbitre. Introdução, texto, tradução e notas por Éric Junod. Paris: Du Cerf, 1976, p. 219.

${ }^{29}$ NEMESHEGYI,S.J. La paternité de dieu chez origène. Paris: Desclée \& Cie, Éditeurs, 1960, p. 141-142.

${ }^{30}$ CROUZEL, H. SI. Origène et la philosophie. Paris: Aubier, 1962, p. 46.

${ }^{31}$ PLATON. Oeuvres completes. Tome troisième. Théetète 176b. Tradução e notas de E. Chambry. Paris: Garnier Frères, 1950, p.381. 
vinculada ao corpo não estará inteiramente dentro do corpo, mas se dividirá entre o corpóreo e o incorpóreo e será esta última parte da alma que se conduzirá para o mundo imaterial, eterno, simples e perfeito, ideia exemplar e inteligível, que se traduzirá na concepção de Deus. A tendência monoteísta da Filosofia religiosa grega cumprirá um imenso trabalho de preparação ao cristianismo:

\begin{abstract}
Numenios tende a uma separação violenta e a um combate; para ele, com efeito, o mal provém da matéria; como Platão, ele julga que para a alma toda incorporação é um mal. Mas visto que a alma, de fato, encarrega-se de um corpo, não lhe resta senão se separar o quanto possível; é o que faz ao menos a alma racional, a única divina, a única capaz de reencontrar o Bem. Pois a alma individual se divide em duas almas independentes, uma racional, a outra irracional, imitando assim o desdobramento da alma do mundo, que, iniciada desde Xenócrates, resulta em duas almas, uma soberanamente benéfica, a outra perversa, a saber a matéria: duas mundi animas..., unam beneficentissimam, malignam alteram, scilicet silvam. ${ }^{32}$
\end{abstract}

Da imagem de César na moeda à alma do homem, da alma do homem à imagem de Deus. Vimos que do ponto de vista político a autoridade secular prevalece em comparação ao espírito, mesmo considerando que tudo tende para a unidade. ${ }^{33} \mathrm{O}$ que pertence à esfera do sensível deverá permanecer no âmbito das coisas deste mundo, tais como taxas, tributos, impostos, negócios... A comparação entre a imagem de César e a alma humana está circunscrita a sua dimensão terrena, sobretudo quando o alexandrino admite que a imagem refletida da moeda é revalorizada e ligada à alma presa ao corpo, como diria Platão, e às doutrinas que valorizavam a transcendência da alma. Digamos que esta parte da alma refletida na moeda seja a pior parte, porque está localizada na parte mais inferior da tipologia tricotômica de alma proposta pelo alexandrino.

Como vimos com a divisão e organização que Numenios opera com a noção de alma, Orígenes seguirá uma divisão muito parecida, embora numa perspectiva cristã, lembrando os Gálatas $(5,17)$ : “A carne desejará contra o espírito”. É importante perceber que há um redobro da noção de imagem, a saber, a alma ílica e a psyque, e, embora esta última esteja localizada em um nível inferior em relação ao Espírito, será justamente neste lugar intermediário entre a carne e o espírito que residirá o livre-arbítrio, valorizando a consciência como o lugar apropriado a deliberações se devemos obedecer às leis escritas e valorizar a conduta virtuosa e justa voltada para a contemplação do Espírito ou, ao

\footnotetext{
${ }^{32}$ NUMÉNIUS. Fragments. Texto traduzido por Édouard des Places, S.J. Paris: Les Belles Lettres, 1973, p. 20.

${ }^{33} \mathrm{O}$ movimento da alma de retorno à unidade também pode ser conhecido como Apocatástase, isto é, o retorno final de todos os espíritos criados em harmonia para o amor divino.
} 
contrário, se devemos nos deixar seduzir pelas coisas materiais fazendo com que a alma se afunde cada vez mais na matéria:

Esta possibilidade que nos é dada de poder vencer conforme a faculdade do livre-arbítrio, ou bem nós empregamos com diligência e nós vencemos, ou bem com preguiça, e seremos reduzidos. Se tudo nos é dado para triunfar de toda maneira, quer dizer, para não sermos vencidos de nenhuma maneira, restaria uma razão de combater o que não poderia ser vencido ? $^{34}$

Frente à importância e à força do livre-arbítrio em querer ou deixar de querer alguma coisa, a negligência humana se torna estritamente voluntária, e o pecado, nesse sentido, possuirá um caráter voluntário, que "consistirá na falta de amor provocado pelo orgulho, na presunção da própria capacidade". ${ }^{35}$ As disposições morais dos espíritos determinam suas condições ontológicas. A vontade racional e livre deve empregar com diligência este poder que foi dado por Deus, de se desviar ou não das potências contrárias que têm por origem os movimentos naturais do corpo. Deus criou a natureza racional e incorruptível a sua imagem e semelhança. ${ }^{36}$

A liberdade nos predispõe a aceitar a virtude ${ }^{37}$ como uma condição inevitável para aquele que pensa e vivencia uma tensão interna porque deve escolher entre o que diz respeito ao que é conforme a sua natureza racional ou ceder o lugar para as paixões e os vícios da alma endurecidos pela negligência e petrificados pela malícia. ${ }^{38} \mathrm{O}$ livre-arbítrio se torna um elemento importante para pensar a relação entre a lei natural e a lei secular, assim como, pensamos a vontade da alma dividida entre os desejos da carne e do espírito. A lei secular como representação da lei natural deve gerir os estados e os negócios humanos, assim como a alma deve se voltar para o mundo celestial, aderir ao espírito e vir a ser espiritual.

\section{Conclusão}

Tanto a alegoria que Orígenes desenvolveu referente ao episódio de Mateus (22,21), a respeito do tributo a César e a Deus, quanto a exegese pertinente à Epístola aos Romanos, (13,1-14), a respeito da submissão da alma à autoridade civil, revelam a

\footnotetext{
${ }^{34}$ ORIGÈNE. Traité des Principes III. Introdução e tradução de Henri Crouzel e Manlio Simonetti. Paris: Du Cerf, 1980, p. 167.

${ }^{35}$ Idem, p. 75.

${ }^{36}$ Idem, p. 81.

${ }^{37}$ ORÍGENES. Contra Celso. Tradução de Orlando Reis. São Paulo: Paulus, 2004, p. 452.

${ }^{38}$ ORIGÈNE. Traité des Principes III. Introdução e tradução de Henri Crouzel e Manlio Simonetti. Paris: Du Cerf, 1980, p. 81 .
} 
intrincada relação entre o poder temporal e o poder espiritual. Orígenes colocou em risco sua própria vida, pois experienciou e suportou a crise política do Império e a consequente defesa contra a religião cívica e os ataques - o agir político dos cristãos - que ameaçavam a base ideológica que sustentava e mantinha o prestígio da aristocracia romana.

Há uma complementaridade entre as duas exegeses, porque o fato de dar a César o que é de César significa que se deve respeitar a autoridade secular e ao mesmo tempo respeitar em primeiro lugar a autoridade religiosa, porque esta tem precedência em relação àquela. Retomando mais uma vez os escritos de Marco Rizzi a respeito da imagem do imperador gravada na moeda e a distinção entre o que pertence a César e o que pertence a Deus, estas passagens desvelam uma dimensão horizontal e uma outra vertical. ${ }^{39}$ Numa perspectiva horizontal devemos considerar o ordenamento jurídico e consequentemente sua dimensão sensível; por outro lado, numa perspectiva vertical relembramos a lei natural, seu aspecto espiritual e inteligível.

A teologia da imagem de ascendência alexandrina e, por conseguinte paulina, transita entre o mundo sensível e o inteligível a partir da concepção tripartite de alma, e do livrearbítrio, o qual devemos não apenas compreender como um dever de consciência, mas também como um elemento que reunirá o mundo terreno ao espiritual e sacralizará a imagem da Igreja com seu contributo escatológico, como o único sinal da realidade inteligível. Isso não quer dizer que Orígenes simplesmente tenha transferido o poder do imperador para os representantes da Igreja - mesmo que a história ulterior demonstrasse o contrário, isto é, ratificasse o crescente poder da Igreja semelhante ao que possuía o imperador -, mas o transferiu para todo o gênero humano originalmente criado à imagem e semelhança de Deus.

Poderíamos conjecturar - em vista da metamorfose que conhecemos no curso dos séculos sucessivos, quero dizer, do crescente poder da Igreja e do que permaneceu da administração do império para fortalecer a estrutura eclesiástica - que estivesse no horizonte um projeto ideológico de controle social com o intuito de fortalecer o poder da Igreja em detrimento do poder de Roma, quero dizer, seria demasiado admitir que, embora Orígenes criticasse as honras ao imperador e toda forma de idolatria, a separação entre a Igreja e o Estado resultaria somente na consolidação do poder político da Igreja? Haveria rigorosamente uma separação da esfera religiosa em detrimento da esfera política ou

\footnotetext{
${ }^{39}$ RIZZI, M. Problematiche politiche nel dibattito tra Celso e Origene. In: LORENZO PERRONE. (Orgs.) Discorsi di Veritá: Studia Ephemeridis Augustiniamum. Paganesimo, Giudaismo e Cristianesimo a confronto nel Contro Celso di Origene. Roma: Institutum Patristicum Augustinianum, 1998, p. 210.
} 
somente a transferência de um poder focado na figura do imperador para outra modalidade de poder centralizado na figura do bispo?

Seria temerário, diante de um contexto tão plurifacetado como este, admitir apenas duas alternativas, como se Orígenes estivesse dividido entre os interesses da Igreja, ou que acreditasse sinceramente no fortalecimento do cristianismo como uma religião que atendesse toda a humanidade. A discussão está aberta. Todavia, o que procuramos especular foi a construção do significado de lei secular como a representação da lei natural secularizada.

\section{Referências}

AGOSTINHO. O livre-arbítrio. Tradução, organização, introdução e notas de Nair de Assis Oliveira. São Paulo: Paulus, 1995.

AGOSTINHO. A Trindade. Livro X, 11.18. Tradução de Agustino Belmonte, O.A.R. São Paulo: Paulus, 1994.

CADIOU, R. Junesse d'Origène: histoire de l'École d'Alexandrie au début du IIIe siècle. Paris: G. Beauchesne et ses Fils, 1935.

CROUZEL, H. SI. Origène et la philosophie. Paris: Aubier, 1962.

JAKAB ATTILA. Ecclesia alexandrina: évolution sociale et institutionnelle $d u$ christianisme alexandrin (IIe et IIIe siècles). Bern. P. Lang, 2001.

NEMESHEGYI,S.J. La paternité de dieu chez Origène. Paris: Desclée \& Cie, Éditeurs, 1960.

NUMÉNIUS. Fragments. Texto traduzido por Édouard des Places, S. J. Paris: Les Belles Lettres, 1973.

ORÍGENES. Contra Celso. Tradução de Orlando Reis. São Paulo: Paulus, 2004.

ORIGENE. Commento alla lettera ai romani. Tradução de Francesca Cocchini. Genova: Marietti, 1986.

ORIGÈNE. Philocalie 21-27. Sur le Libre Arbitre. Introdução, texto, tradução e notas por Éric Junod. Paris: Du Cerf, 1976.

ORIGÈNE. Traité des Principes III. Introdução e tradução de Henri Crouzel e Manlio Simonetti. Paris: Du Cerf, 1980.

PLATON. Oeuvres completes. Tome troisième. Théétète 176b. Tradução e notas de E. Chambry. Paris: Garnier Frères, 1950. 
RIZZI, M. La rappresentazione del potere e il potere della rappresentazione In: Bettiolo P. e Firolamo G. (orgs.). Il Dio Mortale: Teologie politiche tra antico e contemporaneo. Brescia: Morcelliana, 2002.

RIZZI, M. Salvezza e legge: Romani 2, 14 da Origene ad Agostino. In: Laura Gaffuri e Rosa M. Parrinello (orgs.) Verbum e ius - Predicazione e sistemi giuridici nell'Occidente medievale. Firenze: Firenze University Press, 2018.

RIZZI, M. Romans 13 Early Christian Exegesis. In: J. Baun, A. Camieron, M. Edwards, M. Vinzent (orgs.) Studia Patristica Vols. XLIV-XLIX. Paris: Peeters, 2010.

RIZZI, M. Giudeocristianesimo, apologetica e alessandrinismo: le dottrine cristane tra II e III secolo.Torino: PubliCatt, 2006.

RIZZI, M. Problematiche politiche nel dibattito tra Celso e Origene. In: Lorenzo Perrone (orgs.). Discorsi di Veritá: Studia Ephemeridis Augustiniamum. Paganesimo, Giudaismo e Cristianesimo a confronto nel Contro Celso di Origene. Roma: Institutum Patristicum Augustinianum, 1998.

RIZZI, M. Gli Angeli delle nazioni nel dibattito tra Celso e Origene. In: Politica e Religione. Brescia: Morcelliana, 2007.

RIZZI, M. 'Plenitudo potestatis': dalla teologia politica alla teoria dello stato assoluto. In: Paola Ventrone e Laura Gaffuri (orgs.). Images, Cultes, Liturgies: immagini, culti, liturgie. Le connotazioni politiche del messaggio religioso. Paris: Open Edition Books, 2014.

RIZZI, M. Some remarks on ambrose's political theology. School of Theology, Faculty of Theology, Aristotle University of Thessaloniki. Greece: Open Journals, 2014.

RIZZI, M. Anticristo: o início do fim do mundo. Tradução de Orlando Soares Moreira. São Paulo: Loyola, 2019.

RIZZI, M. A redescoberta de Orígenes na reflexão filosófico-política entre os séculos XIV e XVI. Revista Hypnos, São Paulo, v.33. $2^{\circ}$ sem., 2014.

VERBEKE.G. L'Évolution de la doctrine du pneuma: du stoicisme a S. Augustin. Paris: Desclée de Brouwer, 1945. 